\title{
EMILY JOHN MANDEL'S STATION ELEVEN AND COVID-19 IN RELATION TO ULRICH BECK'S RISK SOCIETY: A PANDEMIC FACE OF THE MODERN WORLD
}

\author{
Muhammad Farooq \\ Lecturer, Department of Linguistics, \\ The University of Haripur, Haripur, KP, Pakistan. \\ mfarooq@uoh.edu.pk \\ Muhammad Sohaib \\ Lecturer Department of Linguistics, \\ The University of Haripur, Haripur Pakistan \\ Iqra Maheen \\ Lecturer Department of English Abbottabad \\ University of Science and Technology Havelian, Pakistan
}

\begin{abstract}
Ulrich Beck's notion of 'risk society' reveals an ugly aspect of modernity in today's world. It demonstrates bio-ecological and technological terrors in the modern era. The present research paper discusses Emily John Mandel's Station Eleven, a post-apocalyptic science fiction, and the current outbreak of pandemic of Covid-19 in relation to Beck's 'risk society'. Mandel's Station Eleven, like Covid-19, demonstrates the pandemic of 'Georgia flu' that killed millions of people. The paper aims at exploring the risk features of the present world. It exhibits that today's world has started manifesting the ugly face of modernity in the form of terrible biological war which is either a deliberately manufactured one or an outcome of human collective negligent actions resulted in an unwanted catastrophe. The study terms the pandemic as a shared fear and an induced outcome of shared actions across the world.
\end{abstract}

Keywords: risk society, apocalyptic literature, modernity, Covid-19, pandemic.

\section{INTRODUCTION}

Today's world rests on a paradoxical structure of both progress and risk. In the wake of globalization, the post-apocalyptic/ modern world relates to a number of aspects of life, such as technological, economic, politico-religious, socio-cultural, and industrial, etc. In fact, modernity has passed to the post-modern and post-apocalyptic age which is unique for making man a global citizen who feels at home in the entire world due to technological interconnectivity, overlapping of cultures and rapid progress of industrialization. But at the same time, globalization and modernization are not benign processes. The advent of modernity has created risks for the present humans all over the world and it has resulted in ugly and un-wanted consequences in the form of uncontrollability, technological hysteria (created by media), and ecological terror. The current spread of COVID-19 pandemic in the world is one of such curses that modernity brought with itself along with all types of advancement in life. The present research paper discusses Emily St. John Mandel's 2014 novel Station Eleven, a piece of post-apocalyptic science fiction, and the current outbreak of COVID-19 pandemic in relation to Beck's (1992; 1996; 1999) theory of 'risk society' of modernity. Mandel's Station Eleven, like COVID-19, deals with the pandemic of 'Georgia Flu' which killed a number of people (Butsashvili et al., 2007; Plaspohl, Dixon, \& Owen, 2016; 2010). Beck, a renowned German sociologist, has termed modernization and modernity as uninspiring and seemingly inconsequential when considered on individual level, but to have cumulative and terrible consequences sometimes on collective level. The fire-like outbreak and global spread of pathogenic human Covid-19 has sparked the attention of scientists, biologists, politicians, technologists, security forces personnel, teachers, researchers, journalists, doctors, etc. to dig out the mystery of the virus. The present study aims at exploring the risk features of modern world in the miniature world of Emily St. John Mandel's Station Eleven. It 
discusses various pandemics, especially COVID-19, in the light of Beck's (1992, pp. 1-2) theory of 'risk society' which he also terms as 'second modernity' or 'reflexive modernization'.

\section{Statement of the Problem}

The present-day world seems to be resting on a paradoxical existence of progress and risk. On the one hand, modernity has facilitated mankind with marvelous innovations in the fields of science, technology and industry; while on the other, it has started manifesting itself through the ugliest faces of bio-technological and ecological risks which seem to be uncontrollable and beyond the reach of humanity. The present research paper aims at discussing Emily St. John Mandel 's Station Eleven and the current outbreak of pandemic of Covid-19 in relation to Beck's theory of 'risk society'. It indicates 'risk features' in today's world as manufactured hazards and that this Frankensteinish face of modernity is the [in-]direct outcome of collective human actions.

\section{Objectives of the Study}

(a) To explore the risk features of modernization and modernity in Emily St. John Mandel's Station Eleven in relation to Ulrich Beck's theory of 'risk society'.

(b) To discuss the pandemic of Covid-19 in the light of Ulrich Beck's 'risk society'.

\section{Significance of the Study}

The present research study is worth-reading and significant in both, academic as well as social context. Academically, it reveals the disastrous implications of modernization and modernity in today's global world. It discusses the most recent bio-ecological pandemic of Covid-19 which had put the entire world under lock down. Further, it analyzes Emily St. John Mandel's Station Eleven in the light of Beck's notion of 'risk society' which exposes the 'other' or Frankensteinish face of modernity. In social context, the study may be helpful in broadening the overall understanding of the worldwide dangers of the rapid process of modernization in the wake of humanity's desire to go global'.

\section{REVIEW OF LITERATURE}

This section of the article deals with three main areas: (a) Ulrich Beck's theory of 'risk society' as theoretical framework for the present study; (b) the established literature on apocalyptic science fiction; and (c) Etymology of the pandemic covid-19.

\section{Beck's 'Risk Society' and its Implications in the Modern World}

Making progress at the cost of all possible risks has been a major dilemma for the entire world. Man's desire to attain the highest possible level of technological advancement knows no bounds. He knows well that the way to modernity is not without trouble; and yet he is ready to explore it however risky it may be. The modern world has touched the limits of sky by making groundbreaking discoveries, connecting the people across the globe, by launching rapid sources of communication and transportation and turning man as post-modern species who is a global citizen, free from notions such as boarders, nationalism, religion, fixed identity, and other traditional values. This marvelous progress is the good side of modernity. Beck's theory rests on the way world have become a global village. He argues that today's global world has less boarders and it has become mixed technologically, ecologically and in term of socio-cultural values.

However, today's world also reveals the bad side of modernization in form of various ecological, biological, technological, and nuclear terrors. While touching upon the bad face of modernity in today's global world, Beck's notion of 'risk society' which he has also termed as 'second modernity' and 'reflexive modernization', has sparked the attention of scholars from various disciplines such as sociology, psychology, literature, politics, science and history. Beck's theory of 'risk society' is a comprehensive idea regarding the paradoxical nature of human behavior and action regarding technological advancement and the way these apparent advancements make the situation suitable for the mankind for reverse-progress. The theory states that miraculous advancements in various fields of knowledge, e.g., medicine, science and technology makes life very easy as compared to the previous times. However, progress on such tremendous scale brings after-effects that are so devastating for humanity that the so-called progress not only becomes meaningless but sometimes 
proves to be fatal for humanity on individual as well as collective or societal level. While pointing out two different approaches towards the use of technology, Adam, Beck, and Loon, (2000) stated that the use of technology is highly influenced by socio-cultural norms.

Instead of alleviating poverty and making this world a peaceful place to live, the common advancements in science and technology in the present-day world has resulted in harmful genetically modified crops, a degenerated morality, the fear of global warming, the race to make moon and mars inhabitable but making enough nukes to destroy the planet earth, and the numerous diseases which turn into pandemics.

\section{Apocalyptic Science fiction in Literature}

The term 'apocalypse' has its origin in religion. The Apocalypse of John (Bible, King James Version, Revelation) signifies the end of the world. It is derived from Greek word "apokalypsis" which means to reveal. Specifically, any ancient text "containing prophetic or symbolic visions, especially of the imminent destruction of the world and the salvation of the righteous" or "Great or total devastation" (American Heritage Dictionary of the English Language, 2000). Critics (e.g., Ambroży, 2015; Hicks, 2016; Määttä, 2015) have discussed the evolution of [post-]apocalyptic fiction to reach an agreed upon definition of the term. Apocalyptic writing is that which aims to reveal or disclose something hidden. As far as apocalyptic literature is concerned, it is a specific genre of literature which reveals hidden information using supernatural means such as dreams, visions, magical realism, and angelic intermediaries. It mainly focuses the times of catastrophic change as previously well-ordered world views collapse. Apocalyptic writers foresee the world collapsing through different means in their texts. Lewis (1965) stands first among the modern critics of apocalyptic literature who terms the secular version of apocalypse as 'Ludicrous Catastrophe' (p. 184). Moreover, apocalyptic science fiction is concerned with the end of civilization through nuclear war, plague, or some other general disaster. It also focuses on ecological terrors caused by environmental issues as Adam Trexler's (2015) Anthropocene Fiction, for example, shows how climate change has had an impact on fiction genres, e.g., the suspense novel, science fiction, or chiller fiction. Mary Shelley wrote Frankenstein as the first great piece of science fiction. Post-apocalyptic science fiction is written after pandemics and disasters. It includes texts such as Emily St. John Mandel's Station Eleven, Ling Ma's Severance, Albert Camus's The Plague, Stephen King's The Stand and William Maxwell's They Came Like Swallows. The present research focuses on Mandel's Station Eleven as a post-apocalyptic text in relation to Beck's notion of 'risk society'.

\section{Etymological Background to Covid-19}

The recently emerged pandemic of COVID-19 has history. Guang-dong province of China exhibited its existence in 2003. In 2012 it emerged in Middle East too. The former emergence was termed as $(\mathrm{SARS}-\mathrm{CoV})^{1}$. After 10 years it was identified as Middle East respiratory syndrome COVID -19 $(\mathrm{MERS}-\mathrm{CoV})^{2}$. Both types have same family. In former incident 8,273 confirmed cases of infection were reported and it had spread out to Southeast Asia, causing significant outbreaks in China, Hong Kong, Taiwan, Singapore, and Vietnam. In latter incident, 182 confirmed cases were seen. It had spread to Arabian Peninsula, with most cases occurring in KSA, Qatar, Jordan, Oman, United Arab Emirates, and Egypt. The emergence of this pathogens brought great challenge for scientists and medical field because little was known about them. It was considered that they emerge from recognized zoonotic sources, transmitting by spillover events from animals to human on account of dense and close human contact or ecological change. Most of these virus pathogens remained incurable and hence clinical treatment couldn't be developed throughout the history. After the identification of SARS-CoV, it was hypothesized the host of virus was animal and it was guessed that the pandemics emerged initially in China. The evidence demonstrated a clear relation between SARS$\mathrm{CoV}$ and masked palm civets. Bats had been considered as important reservoir for various human

\footnotetext{
${ }^{1}$ Chinese SARS Molecular Epidemiology Consortium. 2004. Molecular evolution oftheSARScovid-

19duringthecourseoftheSARSepidemicinChina. Science 303:1666-1669.

${ }^{2}$ C, Drosten C, Koopmans MP. 2013. Middle East respiratory syndrome covid19neutralisingserumantibodiesindromedarycamels:acomparative serological study. Lancet Infect. Dis. 13:859866. http://dx.doi.org/10 .1016/S1473-3099(13)70164-6.
} 
Farooq, Sohaib, \& Maheen

pathogens and horseshoe bats were shown having detectable antibodies to SARS-CoV proteins and carried covid-19es (Kan et al., 2005). The current pandemic of COVID-19 has brought massive destruction to human lives across the world.

\section{Delimitations of the Study}

The present research paper is delimited to the discussion of bio-technological and ecological terrors resulted from modernity. It analyzes two pandemics, Georgia flu and COVID-19 in the light of Beck's theory of 'risk society'. Rather focusing on the chemistry of the selected pandemics, it specifically deals with the involvement of modern means, as mentioned earlier, that caused transmitting the pandemics across the world within very short span of time. It reveals undesirable aspects of modernity.

\section{Research Questions}

(a) How does Mandel's Station Eleven demonstrate risk features of modern world in relation to Beck's theory of 'risk society'?

(b) How does Covid-19 run under Beck's theory of 'risk society'?

\section{RESEARCH METHODOLOGY}

The present study is a qualitative research as it deals with the depiction of pandemics in postapocalyptic science fiction. The researcher has analyzed Emily John Mandel's Station Eleven and Covid-19 in the light of Ulrich Beck's theory of 'risk society' (1992). Beck's concept of 'risk society' implies ugly aspects of modernity and modernization in the forms of ecological, biological, technological and nuclear terrors in the present-time world. In 'risk society' Beck has given five processes, i.e. globalization, individualization, gender revolution, underemployment and global risks (ecological crisis and the crash of global financial markets. The present study implied globalization and global risks in term of modern means of communication and transportation as root causes in outbreak and spread of the epidemic viruses in the selected sources. In the light of selected theory, the pandemic of Georgia flu and covid-19 manipulated ecological system and got spread through modern means of communication and transportation. Through content analysis technique selected contents/passages have been analyzed. Further, direct research method was used to examine the selected sources in the light of Beck's selected theory directly.

\section{RESULTS AND DISCUSSIONS}

\section{Emily St. John Mandel's Station Eleven and the Dangers of Modernity}

Emily St. John Mandel has marked great success in the realm of apocalyptic science fictions in literature. She has authored four books among which the last titled Station Eleven (2014) became the bestseller according to The New York Times. The book has recently earned the Arthur C. Clarke Award for apocalyptic science fiction in Literature. The novel deals with dangers of modernity in today's global world. Station Eleven concerns about the changes from old world, we used to be in, to the threats of new world particularly the outbreak of epidemic diseases spreading across the modern world. It is a post- apocalyptic science fiction and exhibits modern world stuffed with celebrities along with common people struggling to enhance the standard of their lives, making unbelievable success, and climbing the ladder of success until the eleventh hour comes which metaphorically indicates to the tipping point of the modern world. John Mandel in an interview with the National Book Foundation remarked, "I've always been interested in writing about memory, and in what it means to live honorably in a damaged world". The novel has two main narratives, the one indicates to the world prior to the spread of Georgia flu, and it demonstrates the famous actor, Arthur's life. The other narrative reveals post-apocalyptic world which focuses the Shakespearean Travelling Symphony. The novel has explicit references to other works of art such as Shakespeare's King Lear. The writer has also used another literary allusion of A Midsummer Night's Dream in the novel.

Travelling Symphony in the novel symbolically indicates to the modern world in which people have become connected globally. The celebrities in the novel are engaged in theatrical performances of King Lear but suddenly are grieved and silenced by the outbreak of pandemic"Georgia Flu". Shakespeare's King Lear bears historical significance in Station Eleven. It indicates to the age of Black Death in the time of Shakespeare which closed door of theatres in England. 
Similarly, the 'Swine Flu' of 2009 and 'Ebola' outbreak in 2014 have great inspirations in the composition of Station Eleven. The fictional pandemic of 'Georgia Flu' in Station Eleven metaphorically projects the worst shape of earlier mentioned pandemics. The story starts with the enactment of Shakespeare's King Lear in which Arthur Leander is a celebrity who dies during the performance due to heart attack at night of the 'Georgia Flu' outbreak. The death of Arthur Leander affects all the characters on the stage because they are deeply dependent and connected with the deceased character. The pandemic of 'Georgia Flu' in Canada, spreads like a neutron bomb on the face of earth and killed million people.

The story tells that approximately ninety percent of people die, leaving the world pockmarked with survivors and the writer says, "Survival is insufficient" which means one needs to bring meaning to one's life and find beauty in the world. The book makes the reader to not take modernity's benefits, such as electricity or communication across oceans for granted. It seems that unknown pandemics would, someday, wipe away everything we entertain from. The following lines from Station Eleven describe the impact of pandemic well:

No more internets. No more social media, no more scrolling through litanies of dreams and nervous hopes and photographs of lunches, cries for help and expressions of contentment and relationship-status updates with heart icons whole or broken (p, 32).

The word 'Eleven' in the title Station Eleven is significant because it metaphorically indicates to the last hours of midnight which follows $12 \mathrm{am}$, changing night to next date. Similarly, English idiom Eleven Hour means the last moment, so it seems, in this context, that the modern world is perhaps at it last stage of success and achievement. This tipping point in the title of the novel symbolizes the catastrophic stage of modern world resulting to a new passage of human life on the earth. Similarly, cinematography titled Eleven Hour film (2007) documented the terrible state of environment projecting that how little things bring big changes on the earth as noted throughout the human history. Station Elven revolves around the central statement:

we have lost for so long, "she said, still quoting from that scene. She looked past him at the boy. The boy was staring at the gun in his hands. He was nodding, seemingly to himself. We long only for the world we were born into $(p, 339)$.

The novel deals with the biological fate of modern human and the trajectories of different human constituencies. It seems that modern world is unpredictable and uncontrollable due to rapid progress and interconnectivity among countries which has resulted a global village. In a time of biotechnology, genomics, and even species revivalism, biological life forms can no longer be considered a stable background for human forms of life. In Station Eleven, the writer has pictured modern world reflecting bio-ecological terrors. It unveils the ugly face of modernity and manifests its dangers. The novel informs the reader that what it means to be in today's globally connected world where technological advancement and other scientific achievements, though taken for granted, but are of serious concerns. The Modern world seems at its eleventh hour of progress which may collapse in the final episode of progress.

\section{COVID-19 and Beck's Notion of 'Risk Society'}

Worldwide outbreak of (COVID-19) has caused lockdown almost in the entire world. The pandemic emerged probably in one region of the world and then it spread in the whole world like forest fire through, most importantly, worldwide traveling. Modern means of communication specifically, technological modes of transportation have really caused its transmission over the world within few weeks. COVID-19 has four fatal features such as Virus, Host, Environment, and Transmission. The present study categorically illustrates the ecological transmission of the pandemic through people's connectivity across the world. The first case of COVID-19 was reported in China in the end of December 2019. The World Health Organization (WHO) ${ }^{3}$ reported that such transmission in China occurred most often at the household level, as 78 percent to 85 percent of disease clusters were family clusters. With the course of time the pandemic spread through multiple chains of people such as travelers, businessmen, cosmopolitans, and other global citizens during their travel to different countries all over the world. By April 2020 most of the world countries have become the worstaffected regions, with Italy, America, and Spain particularly hard hit. After the unavoidable outbreak

\footnotetext{
${ }^{3}$ https://www.who.int/emergencies/diseases/novel-covid-19-2019
} 
of COVID-19, most of the countries started lockdown for people and suggested staying home so that the pandemic could be controlled because there is no such treatment of this fatal virus except certain precautionary measures such as staying home, maintaining social distance, and washing hands frequently. Currently, the whole world has become hysterical planet where people are locked down in homes, industries are shut down, means of transportation are stopped and more importantly the fundamental needs of life are hardly available. There are various damages COVID-19 has brought with all over the world, but the most important ones are bio-ecological damages in the light of modern means of communication and transportation along with socio-economic collapse due to the rapid spread of the pandemic all over the world. Ulrich Beck's notion of risk society, as explained earlier, fits perfectly on the pandemic of COVID-19. The outbreak and rapid spread of COVID-19 all over the world is due to modern means of communication and transportation. His notion of 'risk society' exposes the ugly face of modernization and modernity. The pandemic, since its emergence, has been hitting both; environment as well to human lives all over the world. The virus, according to experts, may spread due to close social contact among people as well as its air transmission at a defined degree is anticipated. According to the latest update of (WHO $)^{4}$ World Health Organization, the pandemic of COVID-19 has affected millions of people, killing one more than one hundred thousand across the world. In this regard the following table exhibits the latest report of covid-19 across the world survey on $30^{\text {th }}$ October 2021.

\begin{tabular}{|l|l|l|}
\hline Total cases of covid-19 globally & Deaths & Vaccinated number \\
\hline $\mathbf{2 4 0 9 4 0 9 3 7}$ & $\mathbf{4 9 0 3 9 1 1}$ & $\mathbf{6 5 4 5 3 0 9 0 8 4}$ \\
\hline
\end{tabular}

\section{CONCLUSION}

The paper concludes that Station Eleven implies risk features in relation to 'risk society' proposed by Beck. The novel is a post-apocalyptic text and reveals the dangers of modernity through fictional representation of how society suffered from Georgia flu and implies historical resonance to terrible pandemics, such as Black Death and Swine Flu which killed millions of people across the globe. It also reveals ecological changes as result of global connectivity and rapid bio-technological progress. Similarly, the pandemic of Covid-19 is an apocalyptic phenomenon and it bears worldwide risk features. The pandemic is spreading over the world through modern means of communication and transportation. The study shows that modern world has become a 'risk society' and these risks, as discussed above, are manufactured ones. Station Eleven and Covid-19 manifest the unpleasant face of modernity in the forms of pandemics resulted from human collective actions. The study shows that modernization and modernity has made the world 'risk society' due to the global connectivity and hence the rapid spread of the epidemic viruses is further accelerated through the modern means of communication and transportation.

\section{REFERENCES}

Adam, B., Beck, U., \& Loon, J. V. (Eds.) (2000). The risk society and beyond: Critical issues for social theory. London: SAGE Publications Ltd. doi: 10.4135/9781446219539

Ambroży, P. (2015). The limits of language as the limits of the world: Cormac McCarthy's and David Markson's post-apocalyptic novels. Text Matters, 5, 62-78. https://0-doiorg.pugwash.lib.warwick.ac.uk/10.1515/texmat-2015-0006

Beck, U. (1992). Risk society: Towards a new modernity. London: Sage Publications, Inc.

Berger, J. (1999). After the End: Representations of Post-Apocalypse. Minneapolis: University of Minnesota.

Butsashvili, M., Triner, W., Kamkamidze, G., Kajaia, M., \& McNutt, L. (2007). Knowledge and anticipated behavior of health care workers in response to an outbreak of pandemic influenza in Georgia. Journal of Infection in Developing Countries, 1(3), 329-332. DOI: https://doi.org/10.3855/jidc.373

\footnotetext{
${ }^{4}$ https://www.who.int/emergencies/diseases/novel-coronavirus-2019
} 
Eve, M. P. (2018). Reading very well for our age: Hyperobject metadata and global warming in Emily St. John Mandel's Station Eleven. Open Library of Humanities, 4(1) DOI 10.16995/olh.155

Feldner, M. (2018). "Survival is insufficient": The Postapocalyptic Imagination of Emily St. John Mandel's Station Eleven. Anglica: An International Journal of English Studies, 27(1), 165-179.

Georgia Flu Cases Prompt Call for Vaccinations. (2010, March 30). New York Times, 159(54995), 18.

Hicks, H. J. (2016). The post-apocalyptic novel in the twenty-first century: Modernity beyond salvage. New York: Palgrave Macmillan

Kaplan, J. (2018). America's apocalyptic literature of the radical right. International Sociology, 33(4), 503-522. https://0-doi-org.pugwash.lib.warwick.ac.uk/10.1177/0268580918775583

Kan, B., Wang, M., Jing, H., Xu, H., Jiang, X., et al. (2005). Molecular evolution analysis and geographic investigation of severe acute respiratory syndrome covid-19- like virus in palm civets at an animal market and on farms. J. Virol. 79: 11892-11900. http://dx.doi.org/10.1128/JVI.79.18.11892-11900.2005.

Lewis, R. W. B. (Ed.) (1965). Trials of the word: Essays in American literature and the humanistic tradition. New Haven: Yale University Press.

Määttä, J. (2015). Keeping count of the end of the world: A statistical analysis of the historiography, canonisation, and historical fluctuations of anglophone apocalyptic and post-apocalyptic disaster narratives. Culture unbound: Journal of current cultural research, 7(3), 411-432. https://0-doi-org.pugwash.lib.warwick.ac.uk/10.3384/cu.2000.1525.1572411

Mandel, E. St. J. (2015) Station eleven. New York: Gale Group.

Méndez-García, C. M. (2017). Postapocalyptic curating: Cultural crises and the permanence of art in Emily St. John Mandel's Station Eleven. Studies in the Literary Imagination, 50(1), 111-130.

Mythen, G. (2004) Ulrich Beck: A Critical Introduction to the Risk Society. London: Pluto Press.

Plaspohl, S. S., Dixon, B. T., \& Owen, N. (2016). The effect of the 1918 Spanish influenza pandemic on mortality rates in Savannah, Georgia. Georgia Historical Quarterly, 100(3), 332-339.

Sørensen, M. P., Christiansen, A., \& Sørensen, M. P. (2013). Ulrich Beck: An introduction to the theory of second modernity and the risk society. London: Routledge.

Trexler, A. (2015). Anthropocene fictions: The novel in a time of climate change. Charlottesville: University of Virginia Press. 